\title{
Perspectives
}

\section{Reexamining Notions of the L2 Syllabus}

Mark James

My first experience working on an English-as-a-second-language (ESL) syllabus was a few years ago when I was teaching at a private English conversation school in Japan. I was asked to lead a small group of teachers in developing syllabuses for 15 levels of classes that included classes for children, teenagers, and adults. Relying mainly on instinct, we used models we found in the front of textbooks and inserted our own lists of grammar points, functions, and vocabulary; a couple of months later, however, the teachers were either finding the new syllabuses difficult to use or had stopped using them completely. My first syllabus project was a flop.

Since then I have had experience with and been a keen observer of ESL syllabus development and use in different teaching situations overseas and in Canada. Consistent with my own earlier experience, I have noticed that (a) the various participants in an ESL instructional setting seem to recognize in a general sense the value of a syllabus (i.e., students and teachers want the kind of guidance that a syllabus can provide; administrators appreciate the accountability that a syllabus brings and its potential for marketing); and (b) there is often a lack of understanding among practitioners of what a syllabus is (or could be), which in turn has a negative impact on both syllabus development and use.

My interest in ESL syllabus development has also led me to notice a relevant gap in the second language (L2) education literature. The syllabus was a source of interest here particularly in the 1970s (e.g., work on functional and notional syllabuses [Van Ek \& Alexander, 1975; Wilkins, 1976] and the 1980s (e.g., introduction of the task-based syllabus [Nunan, 1989; Prabhu, 1981] and several books on L2 syllabus development [Nunan, 1988; White, 1989]. This work contributed a great deal to our understanding of the nature and role of the L2 syllabus. However, in the last 10 years, as the broader field of L2 education has continued to evolve, it seems that less attention has been given to the syllabus in the literature.

Given the crucial role a syllabus can play (and, many would agree, should play) in an ESL program, I think it is necessary to redirect attention to and reexamine our understanding of the $\mathrm{L} 2$ syllabus. This article is an attempt to do so and is structured around three questions that were derived from the situations described above:

1. What is the L2 syllabus? 
2. Are these notions of the L2 syllabus current?

3. How can (or should) these notions be reflected in practice?

\section{What is the L2 syllabus?}

To begin with, the term syllabus needs to be defined. This in itself has been a source of debate, as some researchers have preferred relatively narrow definitions (Widdowson, 1984), whereas others have opted for broader definitions (Allen, 1984). Generally speaking, though, a syllabus outlines what to teach; in other words, it refers to the content, objectives, and sequence of instruction. As Stern (1984) explains, an L2 syllabus is "the specification of the what of instruction or its content, the definition of a subject, the ends of instruction, what is to be achieved, and what will be taught" (p. 5) (note that although in North America the term curriculum is often used interchangeably with syllabus, here a distinction is made: The syllabus is only one component of a curriculum-which in addition to the syllabus may also include things like statements of instructional philosophies, needs assessments, learning materials, tests, and program evaluations).

There are different types of L2 syllabuses. For example, Brown (1995) lists the following: (a) structural, (b) situational, (c) topical, (d) functional, (e) notional, (f) skills-based, and (g) task-based. Another type is the lexical syllabus (Willis, 1990). Each of these types represents a different principle of organization: The structural syllabus, for example, is organized around grammar rules, whereas the lexical syllabus is organized around vocabulary.

Much of this variety in syllabus types has to do with different views of the nature of language. From the perspective of the structural syllabus, for example, language is a set of rules that can be learned by studying grammar. The functional syllabus, on the other hand, sees language as a tool that is used to serve specific purposes (e.g., politely expressing one's opinion); to learn the language requires awareness of the functions it is used for. Therefore, different views on the nature of language have resulted in some of the differences between $\mathrm{L} 2$ syllabuses.

However, the variety in L2 syllabus types also reflects different starting points for syllabus design. Many of the syllabus types referred to above are based on a concern for the language that is to be learned. For example, even though the structural and functional syllabuses view language in different ways, they are similar in that the starting point for both is language. This is probably a reflection of the strong influence the discipline of linguistics has had on L2 education. An alternative, however, is to take learning-as opposed to language-as a starting point. For example, the task-based syllabus mentioned above is organized not around language items, but around instructional activities. The primary rationale for this kind of syllabus comes from the disciplines of psychology and education, not linguistics. 
From a syllabus perspective, these starting points-language and learning - can be seen as, respectively, product and process. In this way, a distinction can be made between product-oriented and process-oriented L2 syllabuses: A product-oriented syllabus emphasizes the language to be learned; a process-oriented syllabus focuses on how language will be learned. Nunan (1988) has drawn attention to this distinction; it is also reflected in (a) Allen's (1984) analytic (i.e., product-oriented) and experiential (i.e., process-oriented) approaches to curriculum planning; and (b) White's (1989) description of Type A (i.e., product-oriented) and Type B (i.e., processoriented) syllabuses. The distinction between the two can be outlined as follows:

In relation to language teaching syllabuses, these two types can be summarized in terms of the distinction between an interventionist approach which gives priority to the pre-specification of linguistic or other content or skill objectives on one hand [i.e., product-oriented syllabus], and a non-interventionist, experiential, "natural growth" approach on the other [i.e., process-oriented syllabus]. (White, 1989, p. 45)

\section{Are these notions of the L2 syllabus current?}

To answer this question, I wished to see how well these established notions of the L2 syllabus fitted with more recent developments in the field. I chose to do this by looking at content-based language instruction (CBI). This seemed a reasonable choice because CBI has grown in popularity, particularly over the last decade, and appears to be a significant part of contemporary L2 education. So if established notions of the syllabus are to be considered current, they should fit with CBI.

Examining this fit requires a clear understanding of CBI. In contrast to more traditional instructional approaches that focus on decontextualized linguistic knowledge (e.g., grammar, vocabulary) or skills (e.g., speaking, reading), $C B I$ involves "the integration of particular content with languageteaching aims" (Brinton, Snow, and Wesche, 1989, p. 2). For example, attention to linguistic knowledge and skills may be encouraged while students are working with content (i.e., substantive material) that deals with a subject or topic like geography or psychology. The underlying assumption is that dealing with content in the L2 will facilitate L2 acquisition. As for a syllabus, that typically associated with CBI is the topical syllabus (Brown, 1995; White, 1989). For example, for a CBI course that is meant to integrate geography content and language learning, the syllabus might specify topics related to physical geography, economic geography, and cultural geography that the students are supposed to learn about.

At first glance, the fit between CBI and established notions of the L2 syllabus appears to be neat: The CBI topical syllabus involves the prespecification of content and therefore has an ostensible focus on the what of 
learning; as a result, it has been classified as a product-oriented syllabus (Long \& Crookes, 1992; White, 1989). However, a closer look suggests that there are problems with this classification.

First, product-oriented syllabuses have certain characteristics that the CBI topical syllabus does not share. For example, at the core of product-oriented syllabuses is a focus on language; the CBI topical syllabus, however, emphasizes substantive material the learners are expected to understand, not the specific language they are expected to understand or produce. In other words, the CBI topical syllabus focuses on the what of learning from a general education perspective, but not from a more specific language learning perspective. Another difference is that product-oriented syllabuses receive little support from research on L2 acquisition (White, 1989); in contrast, L2 acquisition research is very much in support of $\mathrm{CBI}$ and by extension its topical syllabus (Snow, 1998).

Second, the CBI topical syllabus has some aspects that fit with the definition of process-oriented syllabuses. For example, a process-oriented syllabus "aims to immerse learners in real life communication" (Allen, 1984, p. 65). This is clearly the case with this topical syllabus, through which learners focus on understanding and communicating about authentic oral and written substantive material in their L2. In addition, with a process-oriented syllabus, the selection and grading of language content is "roughly tuned" in terms of selection and difficulty (White, 1989). The same is true for the topical syllabus: "When the material is organized by topic rather than considerations of linguistic grading, the language exposure may be somewhat random and only 'roughly tuned' grammatically" (p. 68). Finally, process-oriented syllabuses are influenced by views on how learners learn a language; the basis for the syllabus is psychological and pedagogical rather than linguistic (White, 1989). The same is true for the topical syllabus: "Topic selection and ordering will be determined by educational rather than linguistic criteria, as the value of topic lies in the provision of meaningful and relevant content to stimulate motivation and lead to opportunities for meaningful discussion" (p. 68).

This fit between the CBI topical syllabus and the definition of processoriented syllabuses is also consistent with the research that points to CBI's implicit concern with language learning processes:

- Combining content learning and language learning provides a rich source of input to learners. This is significant because exposure to comprehensible input is widely regarded as a vital part of L2 acquisition (Krashen, 1985; Gass \& Madden, 1985).

- The emphasis in a CBI setting on the comprehension of content may encourage learners to negotiate meaning (i.e., use strategies like asking for repetition or clarification) in order to make sure they understand. From an interactionist position, this kind of negotiation is seen as 
important to $\mathrm{L} 2$ acquisition because it contributes to the comprehension of input (Long, 1981; Pica, 1994).

- CBI has potential benefits for learner motivation. For example, learners may value the challenge in understanding the content and feel a sense of accomplishment if they are successful in understanding. In addition, they may find the content intrinsically interesting. These factors can affect learner motivation, which is significant because motivation has long been seen as a crucial factor in L2 acquisition (Gardner, 1985;

Crookes \& Schmidt, 1991).

In summary, although the topical syllabus associated with CBI appears to fit in the category of product-oriented syllabuses (and has been placed there by researchers), a closer look indicates that (a) it is different from productoriented syllabuses in important ways; and (b) it shares significant characteristics with process-oriented syllabuses. Therefore, it seems that CBI cannot be classified neatly using the product-process conceptualization of the L2 syllabus. As a result, these established notions need updating.

\section{How can (or should) established notions of the L2 syllabus be reflected in practice?}

Naturally, the distinction between process- and product-oriented syllabuses has led to debate about which kind is "best" in practice. Arguments have been made in favor of both product-oriented (Widdowson, 1984) and process-oriented (Breen, 1984) syllabuses. To examine this debate, I decided again to use content-based language instruction as a lens, as well as to consider other relevant branches of the L2 education literature.

The CBI topical syllabus is implicitly concerned with language-learning processes; therefore, the relative success of CBI (see Snow, 1998, for a summary) may be seen as support for the use of process-oriented syllabuses. However, CBI does have shortcomings that are relevant here. For example, in one well-known model of CBI-Canadian French immersion programsstudents have tended to show high levels of language comprehension; however, their language production skills (e.g., grammatical accuracy) fall short of native speaker competence (Swain, 1984). Concern over this has been the impetus behind recent research on a more explicit focus on the formal features of language (Doughty \& Williams, 1998) - which reflects aspects of the product-oriented syllabuses.

In addition, it would be a mistake to ignore the existing wealth of knowledge related to product-oriented syllabuses. For example, there is a substantial body of research on the linguistic and academic needs of international students at the postsecondary level (see Waters, 1996, for a review). Research findings here detail the variety of language-related needs these students have (e.g., taking an active part in discussions and seminars, understanding informal lectures, and writing formal, academic English) even after meeting 
the language proficiency admission requirements at a college or university (Light, Xu, \& Mossop, 1987; Hughey \& Hinson, 1993; see Jordan, 1997, for a review). Knowing what the specific language needs of these students are and focusing instruction in those directions would probably be more efficient than waiting for the needs to be addressed incidentally. White (1989) pointed out that some attention to language product in this way could help avoid a potentially directionless form of instruction.

It appears, then, that in practice some kind of balance between product and process in the L2 syllabus is best. In other words, a syllabus that (a) precisely targets the skills and knowledge that students need (i.e., focus on product), and (b) provides guidance to teachers in terms of ways to stimulate student learning (i.e., focus on process) could be expected to be a relatively effective and efficient instructional tool.

What are the outcomes of this examination?

This examination of notions of the L2 syllabus has answered the questions set out at the beginning of this article:

1. What is the L2 syllabus? It is the specification of the what of language teaching; it can be organized based on various principles, but traditionally has been divided into two broad categories: (a) product-oriented, and (b) process-oriented.

2. Are these notions of the L2 syllabus current? No, these notions need updating in order to reflect developments in L2 education.

3. How can (or should) these notions be reflected in practice? For effective, efficient instruction, both product and process should be addressed in the L2 syllabus.

In terms of outcomes, I hope first that this article stimulates practitioners to think carefully about the nature of the syllabus and its role in their own instructional process. A syllabus is not just a checklist of things to be taught; it is also a reflection of how we see our subject and how we think our students learn. As a result, developing or using a syllabus requires more consideration than I have sometimes seen it given (and given it myself!).

A second outcome is the concern that should be raised by the lack of fit between CBI and notions of the L2 syllabus. Syllabus conceptualization is an important consideration in any branch of education; so if it is not being kept up to date with major developments, it suggests some kind of imbalance. In a relatively young and rapidly growing field like L2 education, it is particularly important that development is balanced (i.e., with an effort to keep established ideas current and consistent with newer ideas as they develop) so that there is a strong sense of coherence and the field does not become characterized as being subject to fashions.

A final outcome is the practical question of how to go about achieving a balance between product and process in the L2 syllabus. To begin with, some 
suggestions for doing this can be found in the L2 education literature. For example, Long and Robinson (1998) advocate using a process-oriented taskbased syllabus and drawing students' attention to the language product on an ad hoc basis; Stern's (1992) multidimensional model, on the other hand, employs different syllabuses concurrently (i.e., the language syllabus is product-oriented, whereas the communication/experience syllabus is process-oriented). However, because there are different models and suggestions in the literature, practitioners may have to answer some fundamental questions for themselves. For example, they may have to decide where the balance between product and process should lie (i.e., will there be an equal concern for both product and process, or will there be more concern for one than the other?) In addition, assuming there is a need for a syllabus to be based on a single organizing principle-if it is not, important issues like student placement and promotion become problematic-they may have to decide what the organizing principle should be (i.e., Should it be language product, or learning process? Can the two be synthesized somehow so they can be used as one principle of organization? Or does the answer lie elsewhere, beyond the notions of product and process?) These questions certainly illustrate the challenge to be faced in the application of notions of the L2 syllabus.

\section{Acknowledgments}

Thanks to the following people for help in the preparation of this article: C. James, R. Macksoud, and G. Ness and the TESL Canada Journal editors and reviewers.

\section{The Author}

Mark James is a doctoral student in the Second Language Education Program at the Ontario Institute for Studies in Education of the University of Toronto (OISE/UT).

\section{References}

Allen, P. (1984). General-purpose language teaching: A variable focus approach. ELT Documents, 118, 61-74.

Breen, M.P. (1984). Process syllabuses for the language classroom. ELT Documents, 118, 47-67.

Brinton, D.M., Snow, M.A., \& Wesche, M.B. (1989). Content-based second language instruction. New York: Newbury House.

Brown, J.D. (1995). The elements of language curriculum: A systematic approach to program development. Boston, MA: Heinle \& Heinle.

Crookes, G., \& Schmidt, R.W. (1991). Motivation: Reopening the research agenda. Language Learning, 41, 469-512.

Doughty, C., \& Williams, J. (Eds.). (1998). Focus on form in classroom second language acquisition. Cambridge, UK: Cambridge University Press.

Gardner, R.C. (1985). Social psychology and second language learning: The role of attitudes and motivation. London: Edward Arnold.

Gass, S.M., \& Madden, C.G. (Eds.). (1985). Input in second language acquisition. Rowley, MA: Newbury House. 
Hughey, A.W., \& Hinson, D. (1993). Assessing the efficacy of the Test of English as a Foreign Language. Psychological Reports, 73, 187-193.

Jordan, R.R. (1997). English for academic purposes: A guide and resource book for teachers. Cambridge, UK: Cambridge University Press.

Krashen, S. (1985). The input hypothesis. London: Longman.

Light, R.L., Xu, M., \& Mossop, J. (1987). English proficiency and academic performance of international students. TESOL Quarterly, 21, 251-260.

Long, M.H. (1981). Input, interaction, and second-language acquisition. In H. Winitz (Ed.), Native language and foreign language acquisition (pp. 259-278). New York: New York Academy of Sciences.

Long, M.H., \& Crookes, G. (1992). Three approaches to task-based syllabus design. TESOL Quarterly, 26, 27-47.

Long, M.H., \& Robinson, P. (1998). Focus on form: Theory, research, and practice. In C. Doughty \& J. Williams (Eds.), Focus on form in classroom second language acquisition (pp. 15-41). Cambridge, UK: Cambridge University Press.

Nunan, D. (1988). The learner-centred curriculum. Cambridge, UK: Cambridge University Press.

Nunan, D. (1989). Designing tasks for the communicative classroom. Cambridge, UK: Cambridge University Press.

Pica, T. (1994). Research on negotiation: What does it reveal about second language acquisition? Language Learning, 44, 493-527.

Prabhu, N. (1981). Bangalore project, 1980 (mimeograph). London: Institute of Education, University of London.

Snow, M.A. (1998). Trends and issues in content-based instruction. Annual Review of Applied Linguistics, 18, 243-267.

Stern, H.H. (1984). Review and discussion. ELT Documents, 118, 5-12.

Stern, H.H. (1992). Issues and options in language teaching. Oxford, UK: Oxford University Press.

Swain, M. (1984). A review of immersion education in Canada: Research and evaluation studies. ELT Documents, 119, 35-51.

Van Ek, J.A., \& Alexander, L.G. (1975). Threshold level English. Oxford, UK: Pergamon Press.

Waters, A. (1996). A review of the research into needs in English for academic purposes of relevance to the North American higher education context. TOEFL Monograph Series, \#6. Princeton, NJ: Educational Testing Service.

White, R.V. (1989). The ELT Curriculum: Design, innovation, and management. Oxford, UK: Blackwell.

Widdowson, H.G. (1984). Educational and pedagogic factors in syllabus design. ELT Documents, 118, 23-28.

Wilkins, D.A. (1976). Notional syllabuses. London: Oxford University Press.

Willis, D. (1990). The lexical syllabus. Birmingham, UK: Collins COBUILD. 